\title{
THE CHEMICAL COMPOSITION OF WASTING MUSCLE IN CATTLE SUFFERING FROM CLINICAL JOHNE'S DISEASE
}

\author{
D. S. P. Patterson, W. M. Allen, Sylvia Berrett \\ AND D. SWEASEY \\ Central Veterinary Laboratory, Weybridge \\ AND \\ T. F. SLATER \\ University College Hospital Medical School, London
}

\section{Plate XI}

BESIDES intermittent severe scouring, a constant feature of clinical Johne's disease is the pronounced wasting and weakness of the musculature, leading to eventual prostration. Though the intestinal mucosa is usually thickened as a direct result of infection with Mycobacterium johnei, the degree of thickening is not correlated with the severity of the clinical condition (Pearson, 1908). However, it is possible that a malabsorptive state develops as in Crohn's disease (Card, 1966), which is histologically somewhat similar. This may eventually lead to terminal cachexia, a characteristic clinical feature of Johne's disease in cattle.

The present study consists of a detailed comparison of the chemical composition of skeletal muscle from normal and clinically affected cows, and shows that in wasted muscle morphological changes are paralleled by what might be described as chemical atrophy. In particular, the levels of muscle adenosine triphosphate (ATP) and creatine phosphokinase (CPK) activity are severely reduced, with loss of protein, and decrease in mean muscle-cell size. A brief report of this work has already been published (Patterson, Allen and Slater, 1966).

\section{MATERIALS AND METHODS}

Animals. Two groups of animals provided the muscle samples: six healthy cows and five cows showing marked muscular wasting. Of the latter group, four cows were unequivocally diagnosed as clinical cases of Johne's disease. The fifth cow was severely wasted, but infection with Myco. johnei was not conclusively demonstrated during life.

Muscle biopsy procedure. Samples of obliquus abdominis internus and externus muscle weighing about $10 \mathrm{~g}$ were removed surgically from animals under paravertebral anaesthesia, and kept on ice during the short return journey to the laboratory. For ATP determinations, the metabolic activity of a separate portion of muscle was quenched by dropping it into liquid nitrogen.

Received 12 Jan. 1968; accepted 25 Mar. 1968.

J. MED. MICROBIOL,-VOL. 1 (1968) 
Muscle analysis. With the exception of muscle samples required for ATP estimations, all analyses were performed on homogenates prepared from 1 vol. roughly chopped muscle and 4 vol. ice-cold water in a "Silverson" mechanical homogeniser. The homogenates were prepared, convenient volumes were allotted and the various analyses commenced with a minimum of delay.

Total nitrogen contents of homogenates were estimated by a micro-Kjeldahl procedure.

Protein nitrogen was determined as the nitrogen content of a protein precipitate prepared from the homogenate by adding 4 vol. 5 per cent. phosphotungstic acid in $2 \mathrm{~N}-\mathrm{HCl}$.

Non-protein nitrogen was obtained as the difference between the previous two estimations. This value multiplied by 6.25 (the usual protein $\mathrm{N}$ factor) was regarded as " nitrogenous extractives".

Hydroxyproline was estimated in muscle homogenate by the procedure of Prockop and Udenfriend (1960). This determination was used as an index of the connective-tissue content of the homogenate. As collagen contains about 12 per cent. of hydroxyproline, the muscle hydroxyproline value was multiplied by 8.5 to give the muscle "collagen" content.

Non-collagen protein $(N C P)$ was obtained as the difference between protein (precipitable $\mathrm{N} \times 6.25)$ and the " collagen" contents.

Myoglobin was determined by a carboxymyoglobin procedure described by Patterson and Allen (1966).

Dry weight and water content. Convenient volumes of homogenate were dried to constant weight in an electric oven at $120^{\circ} \mathrm{C}$.

Lipids. An approximate value for muscle lipid content was obtained by extracting finely ground dry muscle with ether overnight at room temperature and re-weighing the fat-free muscle.

Nucleic acids and nucleotides. Protein and nucleic acids were precipitated from muscle homogenates by the addition of an equal volume of ice-cold $2 \mathrm{~N}$-perchloric acid. RNA and DNA were then estimated by determining the ribose and deoxyribose contents of hot 5 per cent. trichloro-acetic acid extracts of the precipitates (Schneider, 1945). For ribose, a quantitative Bial orcinol reagent was used (Dische, 1955) and for deoxyribose, the diphenylamine reaction of Dische (1930) as modified by Mejbaum (1939) was employed. Standard curves prepared from pure samples of nucleic acids in identical assay conditions (Slater, 1956) were employed for the final calculation of nucleic acid concentrations.

Levels of acid-soluble ribonucleotides were estimated in the initial perchloric acid supernates by measuring the absorbances of 10 -fold dilutions in $\mathrm{N}-\mathrm{HClO}_{4}$ at $260 \mathrm{~nm}$. Results were expressed in arbitrary optical density or OD units per $\mathrm{g}$ muscle.

Creatine phosphokinase (CPK) activity. A clear supernatant was prepared from fresh muscle homogenate by centrifuging for $1 \mathrm{hr}$ at $20,000 \mathrm{~g}$ and $0^{\circ} \mathrm{C}$. CPK activity was then assayed in a $0.2 \mathrm{ml}$ aliquot of a 200 -fold dilution of this supernatant in water. The ultraviolet spectrophotometric assay procedure of Tanzer and Gilvarg (1959) was then used in the form of a test kit supplied by the Boehringer Corporation Ltd. Soluble protein was estimated in the enzyme extract by a method previously described (Patterson, 1964).

Adenosine triphosphate content of muscle. A block of frozen muscle was removed from the liquid nitrogen container, weighed (about $2 \mathrm{~g}$ ) and ground to a powder with a pestle and mortar cooled continuously with liquid nitrogen. The powder was transferred to a glass Potter-type homogeniser standing in an ice-bath. To it was added $6 \mathrm{ml} 5$ per cent. $(\mathrm{w} / \mathrm{v})$ perchloric acid; the temperature was raised to $0^{\circ} \mathrm{C}$ and a homogenate was prepared with a loose-fitting nylon pestle mounted on a stainless steel rod rotated mechanically at a speed of 3000 r.p.m. After centrifuging, $2 \mathrm{ml}$ of the clear supernatant was neutralised with $5 \mathrm{~N}$-potassium carbonate solution and allowed to stand in ice for $30 \mathrm{~min}$. to complete the precipitation of potassium perchlorate. The ATP content of a convenient volume of this neutral extract was measured by an ultraviolet enzyme spectrophotometric procedure (test kit supplied by Boehringer Corporation Ltd). 
MusCle IN JOHNE'S DISEASE

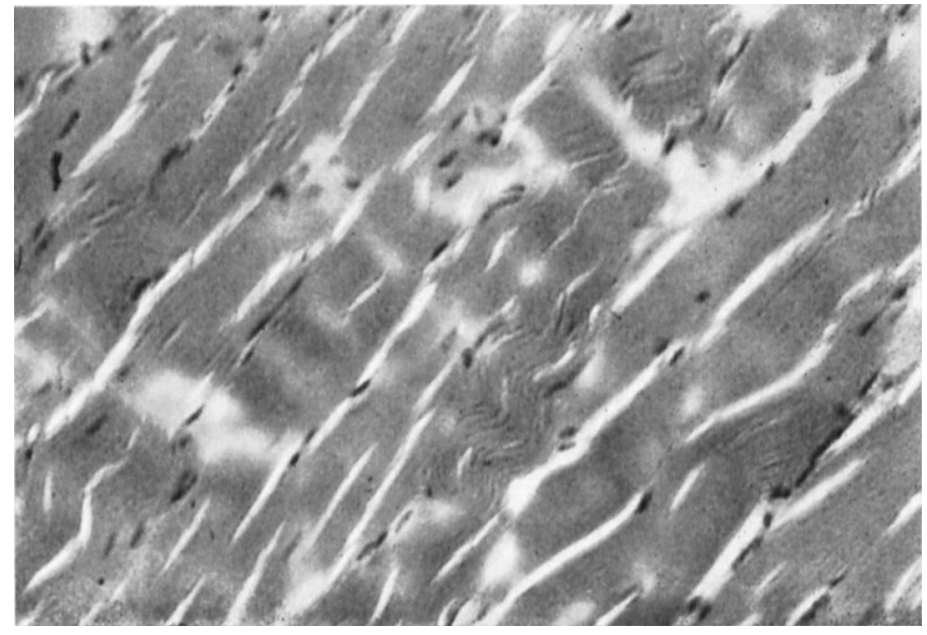

FIG. 1a.-Normal muscle.

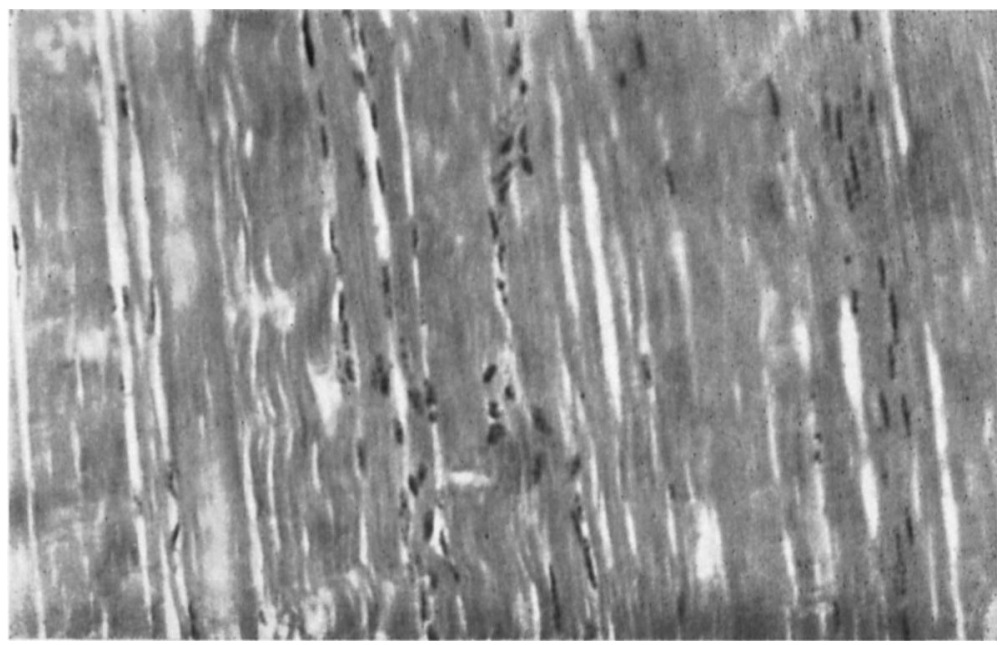

Fig. 1b.-Wasted muscle: diminution in fibre size, and nuclear clumping-a picture similar to that found in human muscle in cachexia (Harriman, 1966).

FIG. 1.-Obliquus abdominis muscle of cows, longitudinal section.

Haematoxylin and eosin. $\times 340$. 


\section{RESULTS}

Chemical composition of whole muscle. The major organic constituents of skeletal muscle obtained from the two groups of cows are compared in table I. Approximately all of the fresh weight was accounted for as protein, lipid, myoglobin, nitrogenous extractives, nucleic acids and water. Inorganic

TABLE I

Major constituents of wasted and normal muscle of cows

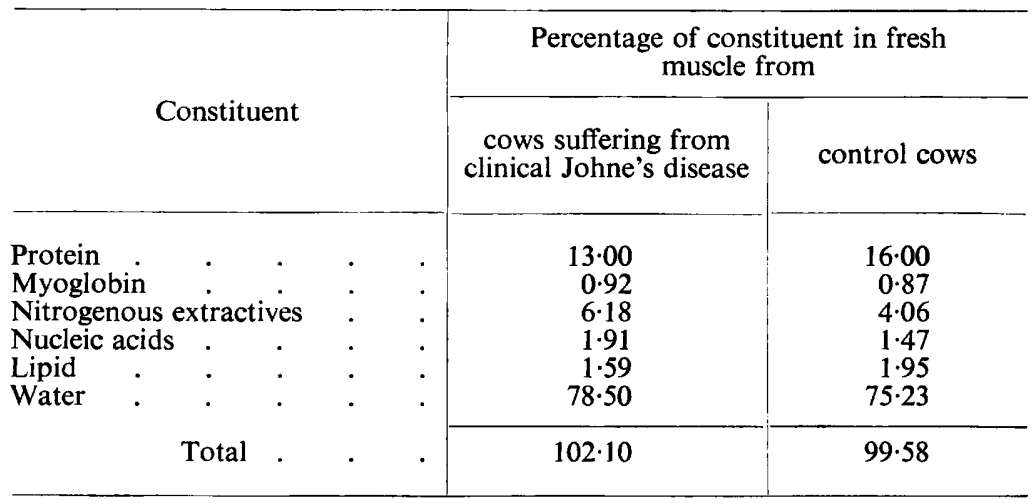

TABLE II

Nitrogenous constituents and water content of wasted and normal muscles of cows

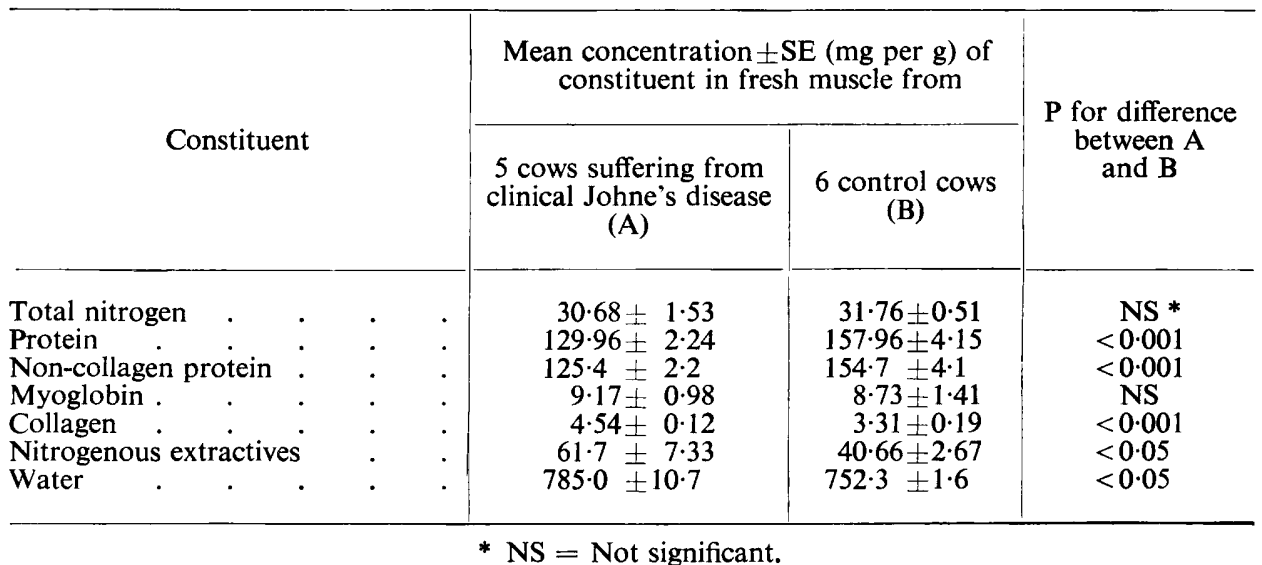

constituents were not estimated, but the ash content of fresh muscle is known to be only about 1 per cent.

Total nitrogen contents of the two groups of muscle samples did not differ significantly, but the protein and non-collagen protein contents of wasted muscle were considerably lower than normal. Thus, the content of " nitrogenous extractives" (amino-acids, peptides and polypeptides) was significantly higher in Johne's disease. Unlike the level of proteins generally, the concentration of myoglobin in fresh muscle was apparently unaltered, but the " collagen" 
content was significantly raised. The total water content of wasted muscle was slightly but significantly raised (table II).

Muscle nucleic acid analysis showed no significant difference in RNA content of the two groups, but a highly significant difference in the DNA

TABLE III

Nucleic acids and nucleotides in wasted and normal muscle of cows

\begin{tabular}{|c|c|c|c|c|}
\hline \multirow[b]{2}{*}{ Determination } & & \multicolumn{2}{|c|}{ Value (mean $\pm S E$ ) in } & \multirow{2}{*}{$\begin{array}{l}\mathbf{P} \text { for difference } \\
\text { between } A \\
\text { and } B\end{array}$} \\
\hline & & $\begin{array}{l}5 \text { cows suffering from } \\
\text { clinical Johne's disease } \\
\text { (A) }\end{array}$ & $\begin{array}{l}6 \text { control cows } \\
\text { (B) }\end{array}$ & \\
\hline $\begin{array}{l}\text { RNA (mg per } \mathrm{g} \text { fresh muscle) } \\
\text { DNA (mg per } \mathrm{g} \text { fresh muscle) } \\
\text { RNA/DNA ratio } \\
\text { Acid-soluble ribonucleotides } \\
\text { (arbitrary OD units per } \mathrm{g} \text { ) }\end{array}$ & $\dot{.}$ & $\begin{array}{l}1.04 \pm 0.092 \\
0.87 \pm 0.031 \\
1.22 \pm 0.105 \\
67.2 \pm 5.45\end{array}$ & $\begin{array}{l}1 \cdot 13 \pm 0.035 \\
0.34 \pm 0.008 \\
3.31 \pm 0.030 \\
60.0 \pm 1.12\end{array}$ & $\begin{aligned} & \text { NS } \\
< & 0.001 \\
< & 0.001 \\
& \text { NS }\end{aligned}$ \\
\hline
\end{tabular}

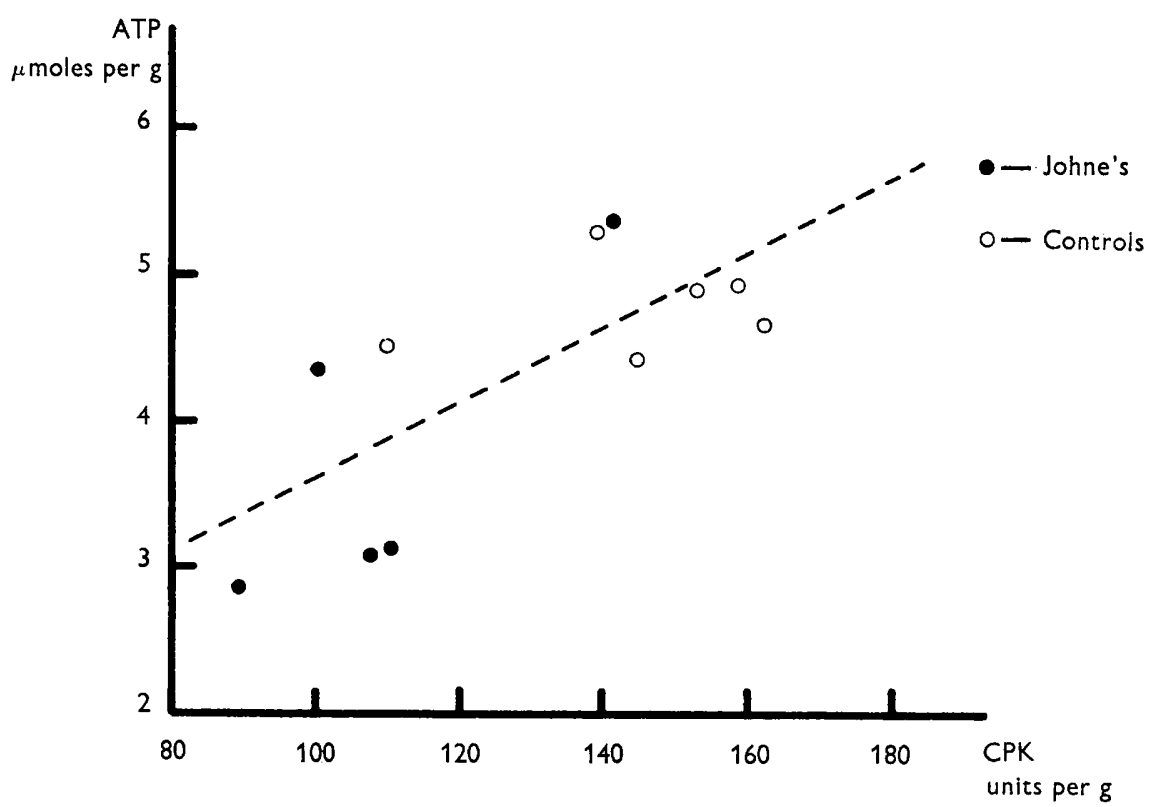

FIG. 2.-Relation between ATP content and CPK activity for normal and wasted muscles. Correlation coefficient $(r)=+0.732(P<0.05)$. Regression equation: $y=1 \cdot 18+0.027 x$.

content was observed (table III). This increase paralleled the increased numbers of nuclei per field when wasted muscle sections stained with haematoxylin and eosin were examined by light microscopy (fig. 1).

The ATP content of fresh wasted muscle ( $\mu$ moles per $\mathrm{g}$ ) was not significantly different from the values obtained for normal muscle, but the mean level of muscle CPK activity was some 25 per cent. lower ( $\mathrm{P}$ for the difference $<0.05$ ). 
Even so, the ratio ATP content : CPK activity was not significantly different for the two groups. In fact, ATP and CPK values for wasted and normal muscle could apparently be fitted to a single regression line (fig. 2).

TABLE IV

The ATP content and CPK activity of wasted and normal muscles of cows

\begin{tabular}{|c|c|c|c|}
\hline \multirow{2}{*}{ Determination } & \multicolumn{2}{|c|}{ Values (mean $\pm \mathrm{SE}$ ) in } & \multirow{2}{*}{$\begin{array}{l}\mathbf{P} \text { for difference } \\
\text { between } \mathbf{A} \\
\text { and } \mathbf{B}\end{array}$} \\
\hline & $\begin{array}{l}5 \text { cows suffering from } \\
\text { clinical Johne's disease } \\
\text { (A) }\end{array}$ & $\begin{array}{l}6 \text { control cows } \\
\text { (B) }\end{array}$ & \\
\hline CPK activity (international units & $109 \cdot 9 \pm 8 \cdot 8$ & $144 \cdot 9 \pm 7 \cdot 8$ & $<0.05$ \\
\hline $\begin{array}{l}\text { CPK specific activity (international } \\
\text { units per } \mathrm{mg} \text { supernatant protein) }\end{array}$ & $1.57 \pm 0.056$ & $2 \cdot 29 \pm 0 \cdot 138$ & $<0.01$ \\
\hline $\begin{array}{l}\text { ATP content ( } \mu \text { moles per } g \text { fresh } \\
\text { muscle) }\end{array}$ & $4 \cdot 06 \pm 0 \cdot 52$ & $5 \cdot 14 \pm 0 \cdot 14$ & NS \\
\hline $\begin{array}{l}\text { ATP content/CPK activity (fresh } \\
\text { muscle) } \times 10^{2}\end{array}$ & $3 \cdot 67 \pm 0 \cdot 31$ & $3.60 \pm 0.21$ & NS \\
\hline
\end{tabular}

TABLE V

Recalculation * of attributes of skeletal muscle cells in wasted and normal cows in terms of attribute per $\mu \mathrm{g} D N A$

\begin{tabular}{|c|c|c|c|}
\hline \multirow{2}{*}{ Attribute } & \multicolumn{2}{|c|}{ Level of attribute (mean $\pm \mathrm{SE}$ ) in } & \multirow{2}{*}{$\begin{array}{l}P \text { for difference } \\
\text { between A } \\
\text { and B }\end{array}$} \\
\hline & $\begin{array}{l}5 \text { cows suffering from } \\
\text { clinical Johne's disease } \\
\text { (A) }\end{array}$ & $\begin{array}{l}6 \text { control cows } \\
\text { (B) }\end{array}$ & \\
\hline Mean cell mass (as $\mathrm{mg}$ fresh weight & $1 \cdot 16 \pm 0.042$ & $2.96 \pm 0.074$ & $<0.001$ \\
\hline $\begin{array}{l}\text { per } \mu \mathrm{g} \text { DNA) } \\
\text { Protein nitrogen (as mg } \mathrm{N} \text { per } \mu \mathrm{g} \\
\text { DNA) }\end{array}$ & $0.024 \pm 0.0012$ & $0.075 \pm 0.0026$ & $<0.01$ \\
\hline $\begin{array}{l}\text { Nitrogenous extractives (as } \mathrm{mg} \mathrm{N} \\
\text { per } \mu \mathrm{g} \text { DNA) }\end{array}$ & $0.012 \dagger \pm 0.0016$ & $0.019 \dagger \pm 0.0014$ & $<0.01$ \\
\hline $\begin{array}{l}\text { Collagen (as } \mu \mathrm{g} \text { per } \mu \mathrm{g} \text { DNA) } \\
\text { Myoglobin (as } \mu \mathrm{g} \text { per } \mu \mathrm{g} \text { DNA) } \\
\text { RNA (as } \mu \mathrm{g} \text { per } \mu \mathrm{g} \text { DNA) } \\
\text { Acid-soluble ribonucleotides (as } \\
\text { arbitrary oD units per } \mu \mathrm{g} \text { DNA) }\end{array}$ & $\begin{array}{cl}5.21 & \pm 0.27 \\
10.7 & \pm 1.45 \\
1.22 & \pm 0.10 \\
0.078 & \pm 0.0079\end{array}$ & $\mid \begin{array}{cl}9.88 & \pm 0.78 \\
26.25 & \pm 4.75 \\
3.31 & \pm 0.03 \\
0 \cdot 179 & \pm 0.0051\end{array}$ & $\begin{array}{l}<0.001 \\
<0.05 \\
<0.001 \\
<0.001\end{array}$ \\
\hline $\begin{array}{l}\text { CPK (m.units per } \mu \mathrm{g} \text { DNA) } \\
\text { ATP (m } \mu \text { moles per } \mu \mathrm{g} \text { DNA) }\end{array}$ & $\begin{array}{l}0.128 \pm 0.0014 \\
4 \cdot 77 \pm 0.78\end{array}$ & $\begin{aligned} 0.427 & \pm 0.020 \\
15.20 & \pm 0.55\end{aligned}$ & $\begin{array}{l}<0.001 \\
<0.001\end{array}$ \\
\hline
\end{tabular}

* In the main from tables I-IV, to give a measure of cellular concentration per unit of nuclear material.

$\dagger$ Although the mean cellular concentration of nitrogenous extractives was lower in wasted muscle, the proportion of the total $\mathrm{N}$ represented by this fraction was $31 \cdot 7$ per cent. against a normal value of $20 \cdot 5$ per cent.

In wasted muscle from cases of Johne's disease, the specific activity of CPK in $20,000 \mathrm{~g}$ supernatants was markedly reduced (table IV). This may indicate a specific depression of CPK enzyme synthesis in wasted muscle, associated with decreased ATP formation. 
Cellular concentrations of constituents. In the absence of macrophage invasion, the increase in DNA content of muscle could be taken to indicate a generalised shrinkage of the muscle cells corresponding to the increased numbers of nuclei per gramme of muscle. This view was confirmed histologically. For this reason, chemical atrophy of the wasted muscle could best be demonstrated by expressing concentrations of muscle tissue constituents in terms of amounts per $\mu \mathrm{g}$ DNA.

The reciprocal of muscle DNA content gave a measure of mean cell size in $\mathrm{mg}$ fresh weight per $\mu \mathrm{g}$ DNA. A comparison between wasted and healthy muscle showed a vast decrease in mean cell size; muscle from cases of Johne's disease showed about 39 per cent. of the normal value. Muscle constituents such as protein, nitrogenous extractives, RNA, acid soluble ribonucleotides, myoglobin, collagen, CPK activity and ATP when expressed in amounts per $\mu \mathrm{g}$ DNA also showed mean values varying from 30 to 63.2 per cent. of mean normal values (table $\mathrm{V}$ ).

An indication of increased cytoplasmic catabolism was obtained from the fact that concentrations of nitrogenous extractives, expressed in this way, represented on the average 31.7 per cent. of the total nitrogenous matter of wasted muscle compared with 20.5 per cent. for normal muscle.

\section{Discussion}

A result that confirmed one of our earlier observations (Patterson et al., 1968) was the increased water content of skeletal muscle in advanced clinical cases of Johne's disease. More important in the present context is the fact that, in the analysis of fresh wasted muscle, alterations in the values for two parameters (non-collagen protein content and DNA per unit weight of muscle) were sufficient to suggest a generalised cell shrinkage. A reduction in non-collagen protein content denoted a decrease in cytoplasmic protein and the large increase in DNA per unit weight of muscle indicated an increase in nuclear material relative to cytoplasmic mass. The increased proportion of connective tissue in wasted muscle as measured by " collagen " or hydroxyproline content supports this view.

Our results are similar to those of Bartoš et al. (1963) who showed a decrease in muscle non-collagen protein of human cachectic patients, and of Hogan, Dawson and Romanul (1965) who demonstrated that, in denervated atrophic rat muscle, there was a large increase in DNA content per $\mathrm{g}$. The same workers also showed that there was no significant change in the total DNA for a given anatomically defined muscle group, confirming that cell shrinkage, and not proliferation, was occurring. Furthermore as the effect of these two changes was to depress the (non-collagen protein/DNA) ratio, there is good agreement with the biochemical changes seen in the atrophic muscles of kwashiorkor and experimental protein deficiency (Nicholls, 1961).

The parallel decrease in muscle ATP and CPK and the correlation between the two sets of values for normal and wasted muscle stressed a dependence of muscle ATP content on the efficacy of the CPK reaction, which is generally 
recognised as a major pathway for ATP production in muscle. Whatever the mechanism initiating muscle wasting, selective depression of enzymic activity apparently occurs in atrophic muscle (Hogan et al., 1965). It is therefore possible that in clinical Johne's disease CPK activity is depressed by an inhibition of enzyme synthesis, particularly as the specific activity of CPK in extracts of wasted muscle was approximately halved.

Probably as a result of the loss of CPK activity, the mean cellular content of ATP measured in m $\mu$ moles per $\mu \mathrm{g}$ DNA fell to 31.4 per cent. of the normal value. This decrease could account for the weakness of wasted muscle since ATP plays an essential part in the process of muscular contraction (Hasselbach, 1965). As ATP is also involved in the amino acid activation step of protein synthesis (Cohen, 1966) it might be expected that a depletion of this nucleotide would result in a diminished ability to synthesise muscle protein, and this suggestion is strengthened by the observed decrease in RNA/DNA ratio, which usually accompanies depressed protein synthesis (Brachet, 1955). Although experiments with ethionine-poisoned rat liver have shown that protein synthesis can proceed despite quite appreciable decreases in total ATP content, decreases of the order found in wasting bovine muscle are accompanied by a substantial depression of protein synthesis (Villa-Trevino, Shull and Farber, 1963). The effect of ATP depletion on protein synthesis would be expected to be even greater in muscle because of the additional requirement for ATP in the contractile process.

There is conflicting evidence for depressed protein synthesis in muscular atrophy. Some workers have demonstrated increased rates of isotopically labelled amino acid incorporation (Slack, 1954; Diehl and Jones, 1966), whilst others (reviewed by Schapira and Dreyfus, 1959) have observed the opposite effect. Recalculation of the various data in terms of activity per unit weight of DNA rather than wet weight or protein content might reconcile these differences. Using this particular mode of expression (amount of constituent or activity, per $\mu$ g DNA) it appears from the present study that the cellular concentrations of all the major constituents are decreased in wasted muscle to an extent more or less commensurate with the observed reduction in cell size. It is therefore probable that on the same basis protein synthetic activity per $\mu \mathrm{g}$ DNA would also be diminished.

Atrophy of the skeletal muscle cells in Johne's disease could arise in several ways. First, it is possible that protein synthesis might be inhibited or catabolism accelerated by an as yet unidentified factor produced by Mycobacterium johnei itself or by the host animal in response to the growth in vivo of this organism. Secondly, atrophy might result from peripheral nerve lesions; biochemical parallels are to be seen in experimental denervation atrophy. For example, Pearlstein and Kohn (1966) have demonstrated massive loss of muscle protein during the atrophy produced by experimental muscle denervation in rats. Although Albornoz (1957) observed lesions of the sciatic nerve in clinical Johne's disease, we have been unable to find anything similar in a series of more than 30 necropsies. Thirdly, muscle wasting is a well-known clinical feature of malabsorption syndromes and therefore defective protein synthesis in Johne's 
disease could result from impaired absorption of amino acids by the thickened intestinal mucosa. This effect would be reinforced by the enhanced gastrointestinal loss of plasma proteins that has recently been observed in clinically affected cattle (Nielsen, 1966a and $b$; Patterson, Allen and Lloyd, 1967).

Although the relevant metabolic interrelationships in wasting bovine muscle are at present uncertain, underlying disturbances of gut physiology are probably initially responsible for the suppression of muscle protein synthesis. If, as seems likely, this also reduces muscle CPK activity, a reduced availability of ATP would result, which would further depress protein synthesis.

\section{SUMMARY}

Skeletal muscle from normal cows and from cows affected with clinical Johne's disease was analysed for nitrogen, protein, hydroxyproline, myoglobin, RNA, DNA, acid soluble ribonucleotides and ATP contents. Creatine phosphokinase (CPK) activity was also assayed in aqueous muscle extracts.

In wasted muscle from cows with Johne's disease the marked reduction in mean muscle-cell size seen histologically was apparently responsible for the increase in DNA content from $0.34 \mathrm{mg}$ per $\mathrm{g}$ to $0.87 \mathrm{mg}$ per $\mathrm{g}$ fresh muscle. This was confirmed by an associated reduction in non-collagen protein from about $155 \mathrm{mg}$ per $\mathrm{g}$ to $125 \mathrm{mg}$ per $\mathrm{g}$ and an increase in the proportion of connective tissue (about 35 per cent. measured by its hydroxyproline content).

The mean apparent cellular concentrations of the various muscle constituents expressed in amounts per $\mu \mathrm{g}$ DNA fell to between 30 and 63 per cent. of the corresponding normal values and the mean cell size had decreased from 2.96 to $1 \cdot 16 \mathrm{mg}$ fresh weight per $\mu \mathrm{g}$ DNA.

ATP content was statistically correlated with muscle CPK activity for both healthy and wasted muscle samples; the reduced cellular concentration of ATP in wasted muscle was therefore probably related to its decreased CPK activity.

Muscular atrophy in Johne's disease may, therefore, be partly associated with a failure of protein synthesis due to a limited availability of ATP via the CPK reaction. Possible precipitating factors are also discussed.

\section{REFERENCES}

Albornoz, J. E. . . . . . . . 1957. Bull. Off. int. Epizoot., 48, 477.

Bartoš, V., Groh, J., Kvasnicka, J., 1963. Dt. Z. Verdau.- u. StoffwechsKrankh., AND ERBEN, J. 23, 314.

BRACHET, J. .

1955. In The nucleic acids, ed. by E. Chargaff and J. N. Davidson, New York and London, vol. 2, p. 475.

CARD, W. I.

1966. In Textbook of medical treatment, ed. by D. Dunlop and S. Alstead, Edinburgh and London, p. 537.

Cohen, N. R. . . . . . . . . . 1966. Biol. Rev., 41, 503.

Diehl, J. F., AND Jones, R. R. 1966. Amer. J. Physiol., 210, 1080.

Dische, Z. . . . . . . . . . 1930. Mikrochemie, 8, 4.

1955. In The nucleic acids, ed. by E. Chargaff and J. N. Davidson, New York and London, vol. 1, p. 285. 
Harriman, D. G. F. . . . . . . 1966. In Excerpta Med. Int. Congr. Ser. no.

HaSSELBACH, W.

Hogan, E. L., Dawson, D. M., AND RoManUl, F. C. A.

Mejbaum, W.

NichOLLS, L.

NIELSEN, K

,

Patterson, D. S. P.

PATterson, D. D. S. P.

Patterson, D. S. P., Allen, W. M. Berrett, Sylvia, Ivins, L. N., AND SWEASEY, D.

Patterson, D. S. P., Allen, W. M., 1967. Vet. Rec., 81, 717. AND LLOYD, M. K.

Patterson, D. S. P., Allen, W. M., 1966. Biochem. J., 101, 38P. and Slater, T. F.

Pearlstein, R. A., and Kohn, R. R. $\quad$. 1966. Amer. J. Path., 48, 823.

PEARSON, N. L. . . . . . . . . 1908. Amer. Vet. Rev., 32, 602.

Prockop, D. J., ANd Udenfriend, S. . 1960. Analyt. Biochem., 1, 22.

Schapira, G., And Dreyfus, J. C. . . 1959. Amer. J. Phys. Med., 38, 207.

SCHNEIDER, W. C. . . . . . . . 1945. J. Biol. Chem., 161, 293.

SlaCk, H. G. B. . . . . . . . . 1954. Clin. Sci., 13, 155.

Slater, T. F. . . . . . . . . 1956. Ph.D. Thesis, Univ. London.

TANZer, M. L., AND Gilvarg, C. . . 1959. J. Biol. Chem., 234, 3201.

Villa-Trevino, S., Shull, K. H., AND 1963. Ibid., 238, 1757.
1965. Prog. Biophys., 14, 167.

1939. Hoppe-Seylers Z. physiol. Chem., 258, 117. revisedair and D. B. Jelliffe, London, p. 156.

1966a. Acta vet. scand., 7, 321.

Copenhagen, p. 110.

1964. Biochim. Biophys. Acta, 86, 405.

1966. Vet. Rec., 78, 823 .

1968. Res. Vet. Sci., 9, 117.

FARBER, E. 